Studies in African Linguistics

Volume 35, Number 1, 2006

\title{
THE STRUCTURE OF COMPLEMENT CLAUSES IN LUNDA*
}

\author{
Boniface Kawasha \\ Savannah State University
}

This paper provides a functional and descriptive study of complement clauses in Lunda, a language spoken in Zambia. While the structure of infinitival complement clauses is analogous to that found in many languages, other types of complement clauses present unique morphosyntactic features. Some dependent constructions are introduced by complementizers which agree in person and number with the subject of the main clause. These complementizers derive from personal possessive pronouns rather than from the verb of saying, as is the case in some Bantu languages, and they have other functions besides introducing embedded clauses. Other clauses disallow complementizers and the verb shows no temporal reference, coding either the perfect or progressive aspect. The interpretation of time in such clauses is dependent on that of the main clause.

\section{Introduction.}

This paper is a study of the structural properties of the various types of complement clauses in Lunda, a Bantu language spoken in the Northwestern province of Zambia. It does not deal with other kinds of complex constructions such as relative clauses, conditionals and adverbial clauses, as these constructions display different morphological and syntactic behavior from complement clauses. The constructions can be divided into three distinct categories: infinitival complement clauses, clauses without complementizers, and those that are introduced by complementizers. While infinitival complement clauses do not generally seem to be different from those of other languages, one type of finite complement clause presents a unique morphosyntactic feature, in that the complementizer is variable,

\footnotetext{
* I thank two anonymous reviewers, who read the first version of this paper, for their helpful comments.
} 
agreeing in person and number with the subject of the main clause. Additionally, the same type of complementizers introduce the complement of the direct object and the locative noun phrase. These complementizers also appear in interrogative constructions attached to the question morpheme - $d i$ after verbs of saying.

The paper is organized as follows: Section 2 briefly looks at the syntactic and semantic properties of infinitival complement clauses. Section 3 deals with finite complement clauses which disallow complementizers. Section 4 is concerned with complement clauses that are obligatorily introduced by complementizers, and Section 5 provides a summary of the study.

\section{Infinitival Complement Clauses.}

As in other Bantu languages, the verb of an infinitival clause is not marked with tense and lacks an overt nominal subject. In Lunda, an infinitival complement clause is characterized by the verb stem prefixed with the infinitive marker $k u$ With respect to their syntactic behavior, such clauses can further be grouped into two subdivisions, one group of which consists of complement clauses whose verbs lack an expressed subject, while the other type possesses an overtly expressed subject that is different from that of the verb of the main clause.

2.1 Infinitival complement clauses after one-place verbs. The verb of the embedded infinitival complement clause has no overt syntactic subject; the nominal subject remains unexpressed in the clause since it is understood as being the same as that of the verb of the main clause. Semantically, the subject of the main clause is co-referential with the subject of the infinitive complement clause. The verb of the main clause codes what Givón $(1990,2001)$ refers to as "inception, termination, continuation, success, failure, attempt, intent, ability, obligation, and possibility."

(1) a. Mumbanda watumba kacháyi.

mu-mbanda wu -a -tumb -a ka-cháyi.

1 -woman SA1-TNS-plant-fv 12 -finger millet

'The woman planted finger millet.'

b. Mumbanda wamanisha kutumba kachayi.

mu-mbanda wu -a -man -ish -a ku -tumba ka-chayi.

1 -woman SA-TNS-finish-CAUS-fv INF-plant 12-finger millet

'The woman finished planting finger millet.' 
As in English and other languages, the nominal subject mumbanda 'woman' of the main clause in ( $1 b)$ must also be the subject of the embedded infinitive verb kutumba 'to plant'. It is the controller of the dependent clause. Given in (2) below are examples of such complement clauses with different types of predicates.

(2) a. Walómbeli kuya nakunooka kumukála. ${ }^{1}$

wu -a -lómb-el -i ku-ya na -ku -nook -a ku -mu-kála

SA1-TNS-ask -RP-fv INF-go and-INF-take a break-fv LOC-3 -village

'He had asked to go to the village and take a break.'

b. Akwenzi alékeli kuzáta.

a-kwenzi a -a -lek-el -i ku -zát -a

2-youth SA2-TNS-stop-RP-fv INF-work-fv

'The youth had stopped working.'

c. Muntu wakáñenyi kutéma.

mu-ntu wu -a -kañany-en -i ku -tém -a

1 -man SA1-TNS-fail -RP-fv INF-cut down trees-fv

'The man failed to cut down trees.'

d. Ndimi wavulamena kusenda muhínyi.

ndimi wu -a -vulamen-a ku-send -a mu-hínyi

1-farmer SA1-TNS-forget -fv INF-carry-fv 3 -handle

'The farmer forgot to carry the handle.'

As can be seen from the examples in (2), the verbs of the complement clauses ya 'go,' nooka 'rest' in (2a), záta 'work' in (2b), kañanya 'fail' in (2c), and senda

${ }^{1}$ The following abbreviations are used in this paper: APPL applicative, AUX auxiliary, CAUS causative, COMP complementizer, CONJ conjunction, COP copula, DEM demonstrative, FUT future, fv final vowel, IMP imperative, IMPF imperfective, INF infinitive, LOC locative affix, NEG negative, OM object prefix/agreement, POSS possessive, PRO pronoun, POSS possessive, -Q interrogative, QUOT quotative, REL relative clause, RFUT remote future, RP remote past, SA subject prefix/agreement, SUBJ subjunctive, TAM tense, aspect and mood, TNS tense, $1 \mathrm{sg}$ first person singular, $1 \mathrm{pl}$ first person plural, 2sg second person singular, $2 \mathrm{pl}$ second person plural. Numbers denote the various noun classes, $\varnothing$ null subject. Examples in this study are in the Lunda orthography and the velar nasal and the voiced postalveolar fricative are represented by the symbols $\tilde{n}$ and $z h$ respectively. 
'carry' in (2d) lack an explicit subject, and thus are all marked with the infinitive prefix $k u$-. The subject of the complement is understood to be the same as that of the verb of the main clause. This syntactic property is one of the 'behavioral properties' of subjects following Keenan's (1976a) criteria where an overt subject is missing on the verb of the complement clause.

What may be interpreted as the equivalent of English 'how to' complement clauses are infinitival clauses, as they bear exactly the same syntactic structures as infinitival complement clauses in Lunda. In other words, there is no formal and syntactic distinction between dependent infinitival complement clauses and 'how to' dependent complement clauses, as exemplified by the verbs kwiluka 'to know' and kudiza 'to learn' in (3).

a. Yáya welúka kutúña matála.

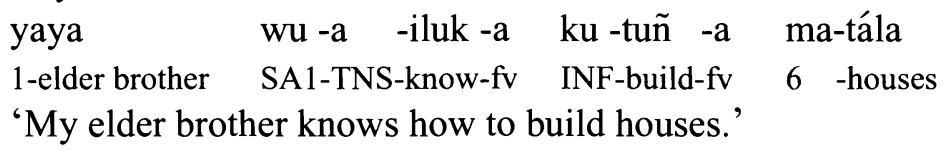

b. Muhela índi wakadíza kuchíma.

mu-hela índi wu -aka -díz -a
1 -sister POSS1 SA1-RFUT-learn-fv
'His sister will learn how to sew.'

In (3a) and (3b), the subjects of the main clause verbs iluka 'know' and diza 'learn' are controllers of the complement clause verbs tuña build' and chima 'sew'. The complement clause comes immediately after the verb of the main clause, just like infinitival complement clauses.

A set of evaluative and emotive state verbs such as kuwáha 'to be good, nice, glad,' kutama 'to be bad,' kutela 'to be worthy of, fit for, suitable to, necessary to' and other impersonal constructions or expressions of evaluation, necessity, obligation, prohibition, and advisability that derive from nouns and adjectives such as wahi 'nice, good, pleasant' chinzhila 'it is forbidden, it is not allowed, it is wrong,' swayi 'quick,' nsónyi 'shame' take infinitival complement clauses. The infinitive is used when an obligation is stated in a general sense without referring to a specific person. The verb or verbal expression of the main clause takes the class 7 subject prefix chi- which functions as an expletive / dummy subject of the main clause. Despite the involvement of the infinitival prefix, the expletive subject prefix does not control the verb of the complement clause. That is, the infinitival clause verb does not require its subject to be co- 
referential with the subject of the main clause. Xhosa and Sotho employ the locative $k u$ - as an expletive subject with such types of verbs (Du Plessis 1982:38). Consider the following Lunda examples:

(4) a. Chachiwáhi kunyámuka lélu. ${ }^{2}$ chachi-wáhi ku-nyámuk-a lélu 7 -good INF-leave -fv today 'It is better to leave today.'

b. Chatéla kufunta swayi.

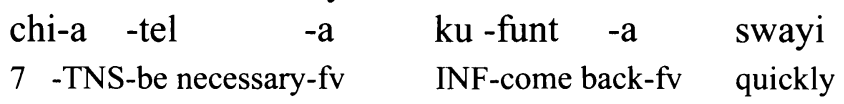

'It is necessary to come back quickly.'

c. Chatáma kuzúña.

chi-a -tama ku -zúñ -a

7 -TNS-be bad INF-fight-fv

'It is bad to fight.'

d. Chakála kuhósha.

chi-a -kala ku -hósh-a

7 -TNS-be hard INF-say -fv

'It is hard to say.'

e. Chinzhila kuhukula mbízhi chochochu.

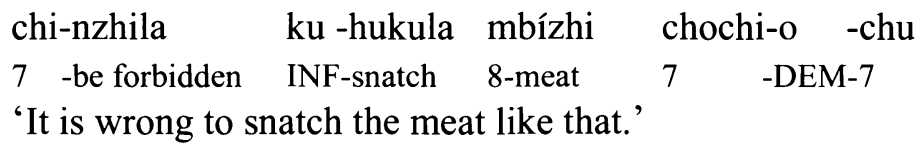

In (4a-e), the subject prefix chi- does not show any control of the subject of the infinitival clause; the subject of the complement clause remains unbound in the sentence and only picks up a referent from discourse. There is nothing to refer to in the main clause.

${ }^{2}$ The adjective wahi 'good' is one of the adjectives that take reduplicated compound agreement prefixes as seen in chachiwahi made up of the morphemes chi-a-chi. 
2.2 Infinitival complement clauses after two-place verbs. The second type of infinitival complement clauses consists of dependent clauses that come after twoplace verbs, which can in turn be subdivided into two distinct subgroups, namely basic non-derived verbs and derived causative verbs. The complement-taking verbs with causative semantics fit well under the subcategory of complementtaking verbs that Givón $(1990,2001)$ describes as manipulate verbs, since they take an agent, and a patient/theme which is also the agent of the complement clause verb. The subject of the infinitive complement clause is not overtly expressed, is independent of the main clause, and is understood to be co-referential with the direct object of the main clause. Consider the following examples that illustrate constructions with infinitival dependent complement clauses occurring after the direct object of the main clause.

(5) Mukwénzi nakukwásha akwawu kubúza kapila kamenzhi. ${ }^{3}$

\begin{tabular}{|c|c|c|c|}
\hline mu-kwénzi & $\varnothing \quad-n a \quad-k u-k w a ́ s h-a$ & a-kwawu & ku -búza \\
\hline $1 \mathrm{sg}$-youth & SA1-TAM-INF-help $\quad-\mathrm{fv}$ & 2-friend & INF-dig \\
\hline $\begin{array}{l}\text { ka-pila } \\
12 \text {-furrow }\end{array}$ & $\begin{array}{l}\text { ka-a } \quad \text {-ma-inzhi } \\
12 \text {-POSS-6 } \quad \text {-water }\end{array}$ & & \\
\hline
\end{tabular}

Walómbeli chilolu kwimana.

wu -a -lómb-el-i chilolu ku -iman -a
SAl-TNS-ask -RP-fv leader INF-stand up-fv
'He had asked the leader to stand up.'

${ }^{3}$ The morpheme $n a$ - is employed to express the present perfect/anterior, in addition to the final vowel $-i$. It also indicates present progressive continuous as well as past continuous when it follows the verb $d i$ 'be,' which may be deleted, plus an infinitive. Consequently, TAM is used as a cover term for this morpheme when it is used as a tense-aspect marker. The first person singular and class 1 subject prefixes delete with this aspectual morpheme. The two are distinguished by tone.

$\begin{array}{llll}\text { Ná-d-i. } & \text { 'I have eaten.' } & \text { Na-d-i } & \text { 'S/he has eaten.' } \\ \text { Ni-di na-ku-da. } & \text { 'I am eating.' } & \text { Wu-di na-ku-da } & \text { 'S/he is eating.' } \\ \text { Ná-ku-da. } & \text { 'I am eating.' } & \text { Na-ku-da } & \text { 'S/he is eating.' }\end{array}$


(6) Kawumba walétésheli Nswana kuleka mudimu.

Kawumba wu -a -let -esh -eli Nswana ku -lek -a mu-dimu

Kawumba SA1-TNS-bring-CAUS-RP Nswana INF-quit-fv 3 -job

'Kawumba caused Nswana to quit his job.'

Mumbanda wakakezha kánsi kúda.

mu-mbanda wu -a -kakezha ka-ánsi ku -d -a

1 -woman SA1-TNS-force 1 -child INF-eat-fv

'The woman forced the child to eat.'

In (5), the verbs kwásha 'help' and lómba 'ask, request' of the main clause are simple non-derived verbs, while in (6) the verbs letesha 'cause' and kakezha 'force' of the main clause are derived causative ones.

When the direct object of the verb of the main clause is expressed as a pronominal prefix, it appears in the preverbal direct object slot of the main clause, and not before the verb of the complement clause, as shown in the following examples.

(7) a. Kawumba wamulétésheli kuleka mudimu.

Kawumba wu -a -mu -let -esh -el -i ku -lek -a mu-dimu

Kawumba SA1-TNS-OM1-bring-CAUS-RP-fv INF-quit-fv 3 -job

'Kawumba caused him to quit his job.'

b. Nayikáñeshi kuya.

$\varnothing \quad-n a \quad-y i \quad-k a \tilde{n}-i s h \quad-i \quad k u-y a$

SA1-TAM-OM2-fail -CAUS-fv INF-go

'He has prevented them from going.'

The prefixes - mu- and -yi- attached to létesha 'cause' in (7a) and káñesha in (7b) are direct object pronouns.

\section{Finite Clauses without Complementizers.}

This section deals with complement clauses that cannot be introduced by complementizers or any other overt sign of subordination, such as verb morphology. Such types of embedded clauses occur immediately after the direct object of the main clause without any intonational pause. The verbs that are used in this type of complement clause are transitive perceptual and evidential complement-taking 
verbs such as móna 'see, discover,' tíya 'hear, feel' wana 'find, discover,' bulakana 'meet,' shiya 'leave behind'.

(8) a. Námona anyikwénzi anakwása nguja.

\begin{tabular}{|c|c|c|c|}
\hline -món-a & a-nyi-kwénzi & a $\quad-n a \quad-k u \quad-a s \quad-a$ & nguja \\
\hline 1 sg-TNS-see -fv & $2-4 \quad$-youth & SA2-TAM-INF-play-fv & 9.soccer \\
\hline
\end{tabular}

b. Náyisiyi ananakwinza.

$\varnothing-a \quad-y i \quad$-shiy -i
1sg-TAM-OM2-leave-fv
'I left them coming.'

c. *Námona námi anyikwénzi anakwása nguja

ni -a -món-a námi a-nyi-kwénzi a -na -ku -as -a nguja 1sg-TNS-see -fv COMP1 2-4 -youth SA2-TAM-INF-play-fv 9.soccer 'I saw that the youths were playing soccer.' (Lit: 'I saw the youths playing soccer. They were playing.')

The nominal object anyikwénzi 'youths' in (8a) and the class 2 object pronominal prefix $-y i$ - in $(8 b)$ are also the subjects of subordinate clauses. This is clearly shown by the presence of the subject agreement prefix $a$-attached to the verb of the embedded complement clauses. The presence of the complementizer námi in (8c) renders the construction ungrammatical.

When the complement clause is a passive construction, the direct object of the main clause triggers a coreferential object agreement marker on the subordinate verb, and the class 2 subject prefix $a$ - fills the subject slot.

(9) Chinenzaña namóni nkáyi anakumuhaña kúdi mutúpa.

chi -ní -a -inz -a -aña $\varnothing$ na -món-i nkáyi

when-1sg.-TNS-come-fv-IMPF 1sg. TAM-see -fv duiker

$$
\begin{array}{llll}
\text { a -na -ku -mu -hañ -a kúdi mu-túpa } & \text { man-fo } \\
\text { SA2-TAM-INF-OM1-chase-fv by } 3 \text {-lion }
\end{array}
$$

'As I was coming, I saw a duiker being pursued by a lion.' 
The nominal direct object nkáyi 'duiker' of the main clause is also the object of the embedded complement clause, as can be seen by the presence of the object agreement marker $m u$ - prefixed to the verb. ${ }^{4}$

The verb of the complement clause does not show any temporal reference, as it may be coded with either the perfect aspect morphology for events completed prior to those encoded by the verb of the main clause, or the progressive aspect for ongoing and simultaneous events and states. In other words, the interpretation of the time of the complement clause is dependent on that of the preceding main clause. Consider the following examples.

a. Wúkuwana atwansi anakuda.

wú -ku -wan-a a-tu-ánsi a -na -ku -da
SA2sg-FUT-find -fv2-13 -child SA2-TAM-INF-eat
'You will find the children eating.'

b. Wúkuwana atwansi anadi.
wú -ku -wan-a a-tu-ánsi
a $\quad$-na $\quad-d-i$
SA2sg-FUT-find -fv2-13 -child
SA2-TAM-eat-fv
'You will find the children have eaten.'

c. Wúkuwana atwansi mwaka ada déhi. ${ }^{5}$
wú -ku -wan-a a-tu-ánsi mwaka
a $\quad-a \quad-d \quad-a$
déhi
SA2sg-FUT-find -fv2-13 -child time SA2-TNS-eat-fv already
'You will find the children had already eaten.'

Complement clauses without complementizers appear more frequently in narratives ${ }^{6}$ and may also be combined with an adverbial clause of time, as illustrated by the examples in (11) and (12) with verbs in the anterior/perfect and progressive aspect respectively.

\footnotetext{
${ }^{4}$ Lunda obligatorily requires the object marker to co-occur with the nominal object when the latter is fronted in passive constructions. This syntactic behavior also applies to left-dislocation.

${ }^{5}$ The noun mwaka 'time, year' in (10c) is used adverbially in combination with the adverb déhi 'already.'

${ }^{6}$ About this type of complement clauses, (White 196? - the last digit of the printed date is not legible in the manuscript) states that the "actions being narrated are commonly referred to as if the actions were being described by a present eye witness".
} 
(11) Chinafuntili, nawéni mukánda wédika déhi, anakuwuzátisha. chi -ni -a -funt -il -i ni -a -wan-in -i mu-kánda when-1sg-TNS-go back-RP-fv 1sg-TNS-find -RP-fv 3 -book wu -a -idik -a déhi a - na $-k u$-wu - zat - ish $\quad$-a SA3-TNS-come-fv already SA2-TAM-TAM-OBJ3-work-CAUS-fv 'When I went back, I found that the book had already come out and was being used.' (Lit: 'When I went back, I found the book has already come out, it is being used.')

(Kakoma 1988:iv)

(12) Chashíkiliyi kwitála, Sayitamba wawéni ñodindi wudi muchinsambu nakwóta kési.

chi -a -a -shik -il -i -yi ku -itala Sayitamba wu -a -wan-in -i when-SA2-TNS-arrive-RP-fv-1 LOC-house Sayitamba SA1-TNS-find -RP-fv ñod-indi wu -di mu -chi-nsambu $\varnothing$-na $-k u$-ota $k a$-isi wife-POSS1 SA1-be LOC-7 -kitchen SA1-TAM-INF-warm self.12-fire

'When he arrived home, Sayitamba found his wife in the kitchen warming herself by the fire side.' (Lit: When he arrived home, Sayitamba found his wife is the kitchen warming herself by the fire side.') (Matoka 1995:63)

\section{Clauses with Complementizers.}

Lunda has three types of finite embedded complement clauses that are introduced by complementizers, depending on the type of the governing predicate which they are associated with. Some clauses come after the prefix chi-, which is used as a complementizer. Embedded interrrogative 'yes-no' complement clauses are headed by the invariable complementizer neyi 'whether,' while the last group of dependent complement clauses comes after variable subject-agreeing complementizers.

4.1 The complementizer chi-. As seen in subsection 2.1, a certain number of emotive and evaluative verbs takes the subject prefix chi-, which functions as an expletive subject. These verbs or verbal expressions also take embedded tensed complement clauses introduced by the complementizer chi-, which is different from the subject prefix, although the two are homophonous and occur as prefixes attached to the verb. The tense expressed in the complement clause does not de- 
pend on the verb of the main clause. The event may be located in the past, present or future tense.

(13) Chinawáhi nánkashi chiwúnénzi.

chi -na -wah -i nankashi chi -wu-na -inz -i

SA7-TAM-be good-fv very COMP-2sg-TAM-come-fv

'It is very good that you have come.'

Nátíyi kuwáha chiwúnénzi.

$\varnothing$-na -tiy -i ku -waha chi -wu-na -inz -i

SA1-TAM-feel-fv INF-be happy COMP-2sg-TAM-come-fv

'I am happy that you have come.'

The prefix chi- appears as a complementizer attached to the verbs kuwaha 'to be happy, to be good' and kutíya kuwaha 'to feel good, to be happy' which are used as an adjective in the main clause.

Nominal subjects occur after the verb in this type of construction, that is, the complementizer forces the nominal subject to move into the postverbal position. In addition, the verb suffixes $-y i$ and $-w u$ for class 1 and 2 subjects respectively. In other words, there are two subject markers - the preverbal subject prefix $a$ - which is the same for both singular and plural, and the postverbal affix. The construction is similar to certain types of adverbial clauses with third person subjects. ${ }^{7}$ However, the treatment of these constructions is beyond the scope of this paper.

${ }^{7}$ The complementizer chi- is different from the class 7, 8 and 9 relativizers $c h i-, y i$ - and $z h i$ used in headless relative clauses with the meaning 'that which' and 'those which'. The relativizer chi- can also be when used adverbially in embedded clauses; it may mean 'if, when, because, how, after, as'. The difference between the two lies in the fact that the clause with a relativizer may be either the subject or the object of the verb.

$\begin{array}{llll}\text { Naýli } & \text { mumpáta } & \text { nami } & \text { nákamóni } \\ \text { ni-a-y-il-i } & \text { mu-mpata } & \text { nami } & \text { ni-ka-mon-i } \\ \text { 1sg-PAST-go-RP-fv } & \text { LOC-bush } & \text { COMP.1sg } & \text { 1sg-FUT-see-SUBJ } \\ \text { zheláña } & & \text { akwétu. } & \\ \text { zhi-a-a-il -aña } & & \text { akwetu } & \\ \text { REL10-3pl-TNS-do-IMPF } & \text { fellow friends }\end{array}$

'I went in the bush so that I could see what my fellow friends do.' 
(14) Chinawáhi nánkashi chanenzíyi mukwénzi.

chi -na -wah -i nánkashi chi -a

SA7-TAM-be good-fv very COMP-SA1-TAM-come-fv-1 1 -youth

'It is very good that the youth has come.'

Nátíyi kuwáha chiyanenź́wu anyikwénzi.

$\varnothing$-na -tiy-i ku -waha chi $-a$-na - inz $-i$-wu

SA1-TAM-feel-fv INF-be happy COMP-SA2-TAM-come-fv-2

a-nyi-kwenzi

$2-4$-youth

'I am happy that the youths have come.'

The verb enza 'come' in (14) is attached with the suffix -yi because the subject is third person class 1 , while that in (14) suffixes the class 2 morpheme -wu for third person plural.

4.2 Embedded interrogative complement clauses. Embedded interrogative complement clauses are introduced by the complementizer néyi 'whether, if'. Some of the verbs that take such dependent complement clauses in Lunda are kwiluka 'to know,' kwíhula 'to ask, to inquire,' kuzhinoka 'to doubt, to consider, to ponder' and the defective verb that expresses doubt kwizhi ${ }^{8}$ 'to wonder, to doubt'.

(15) Kadamaseki wéhwíli múku wíndi neyi akufunta tahinđı́.

Kadamaseki wu -a -ihul-il -i mu-kú wu-a -índi neyi

Kadamaseki SA2-TNS-ask -RP-fv father-in-law 1 -POSS-1 whether

a -ku -funt -a tahindi

2.SA-FUT-go back-fv or not

'Kadamaseki asked his father-in law whether or not they would return.'

${ }^{8}$ Kwizhi is defective in the sense that it cannot be inflected with a subject prefix or tense marker. It always occurs with the infinitive marker $k u$ - and has diverse interpretations such as 'perhaps, doubt, wonder, may be' or just to express uncertainty. 
Hélukíli néyi kwizhi nakulota inđí kwizhi nakutíya mwalala.

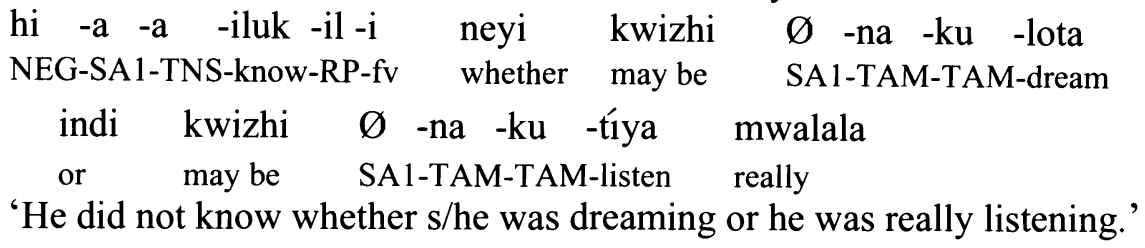

Kwizhi néyi akuya lélu.

kwizhi neyi a -ku -ya lélu

We/I/one wonder whether SA2-FUT-go today

'We/I/one wonder(s) whether they will go today.'

4.3 Subject-agreeing complementizers. It would be worthwhile to talk about independent pronouns and possessive pronouns before introducing the subjectagreeing complementizers, because of the existence of a clear connection between the latter and the possessive pronouns with respect with morphology. The first and second person (both singular and plural) independent pronouns and possessive stems are formally identical. However, there are some differences between the two types of morphemes, in that independent pronouns can stand alone as words, but possessive pronominal stems can only occur attached to agreement prefixes. In addition, the former bears a low tone and the latter carries a high tone on the first syllable. Compare the examples of absolute pronouns in (16) and those of the possessive pronominal stems in (17) below.

(16) Ami násenda chéña.

'I carried a plate.'

ami ni $\quad$-a $\quad$-send-a chéña

PRO1sg. SA1sg.-TNS-carry -fv plate

eyi mukwétu

'you my friend'

PRO2sg friend

Enu ambanda yúma yidi kudihi?

enu a-mbanda yi-úma yi -di kudihi?

'You women, where

PRO2pl. 2-woman 8 -thing SA8-be where are the things?' 
(17) kadidi kámi ka-didi ki-ámi

12 -bed 12-POSS1sg

itéla déyi

'your house'

i-tála

di-éyi

5-house

5 -POSS2sg

maátu énu

ma-átu

a-énu

8 -boat

8-POSS1 pl

'my bed'

'your boat'

The two tables below illustrate independent pronouns and personal possessive pronominal stems.

\section{Table 1. Independent Pronouns}

$\begin{array}{lll}1 \mathrm{sg} & \text { ami } & \text { 'me' } \\ 1 \mathrm{pl} & \text { etu } & \text { 'we, us' } \\ 2 \mathrm{sg} & \text { eyi } & \text { 'you' } \\ 2 \mathrm{pl} & \text { enu } & \text { 'you' } \\ \text { class 1 } & \text { yéna } & \text { 'him/her' } \\ \text { class 2 } & \text { wéna } & \text { 'them' }\end{array}$

\section{Table 2. Personal Pronominal Stems}

$\begin{array}{lll}1 \mathrm{sg} & \text { ámi } & \text { 'my' } \\ 1 \mathrm{pl} & \text { étu } & \text { 'our' } \\ 2 \mathrm{sg} & \text { éyi } & \text { 'your' } \\ 2 \mathrm{pl} & \text { énu } & \text { 'your' } \\ \text { class } 1 & \text { '́ndi } & \text { 'his/her' } \\ \text { class 2 } & \text { áwu } & \text { 'their' }\end{array}$

In Lunda, declarative complement clauses are introduced by complementizers which agree in number and person with the subject of the main clause. That is, the complementizers are variable, as their morphology is determined by the subject of the main clause. They consist of the prefix $n i$-attached to a possessive 
pronominal stem, as illustrated in the examples (18a) through (18f) using different verbs of perception, utterance and cognition with different subject persons.

(18) a. Ami nanúkili námi hinađiñni nankingáku.
ami
ni -a -anuk -ili námi
hi $\quad-n i-a \quad-d i-i n ̃ i$
1 sg 1sg-TNS-remember-RP COMP1sg NEG-1sg-TNS-be-RP
na -nkinga-ku
with-bicycle -NEG
'I remembered that I did not have a bicycle.'

b. Eyi wádikala néyi hináshiña muntúku.
eyi wu -a -dikala-a
néyi
hi $\quad$-ni $\quad$-a $\quad$-shíñ-a
2sg SA2sg-TNS-deny -fv
COMP2sg.
NEG-SA1sg-TNS-curse-fv

$$
\begin{array}{ll}
\text { mu-ntu } & -\mathrm{ku} \\
1 & \text {-person-NEG }
\end{array}
$$
'You denied that you did not curse anyone.'

c. Mukwénzi welúkili níndi mpáta yatelela kuhimpewa.

$$
\begin{gathered}
\text { mu-kwénzi } \begin{array}{cccc}
\text { wu-a } & \text {-iluk -ili } & \text { níndi mpáta } \\
1 \text {-youth } & 1 \text {-TNS-know-RP COMP1 } & \text { 8.country } \\
\text { yi -a -telela ku -himp -ew -a } & \\
\text { SA8-TNS-ought } & \text { INF-change-PASS-fv }
\end{array} \\
\text { 'The youth knew that the country ought to be changed.' }
\end{gathered}
$$

d. Twahayama nétu mahína asukuma kafwampi mukési.

$$
\begin{aligned}
& \text { tu -a -hayam -a nétu ma-hina a -sukuma-a } \\
& \text { 1pl-TNS-be surprised-fv } \quad \text { COMPlpl } 6 \text {-cloth } \quad \text { TNS-burn } \quad \text {-fv } \\
& \text { kafwampi mu-ka-ísi } \\
& \text { as if } \quad 18-12 \text {-fire }
\end{aligned}
$$

'We were surprised that the clothes were burned as if in fire.'

e. Mwatela kwiluka nénu hitwákafuntáku.

mu-a -tel -a ku-iluk -a nénu hi -tú -aka-funt -a -ku 2pl -TNS-ought-fv INF-know-fv COMP NEG-1pl-FUT-return-fv-NEG 'You ought to know that we will not return.' 
f. Akwénzi atóñózhokeli náwu Nswana nenzi nakumwóta. a-kwénzi a -a -toñozhok-eli náwu Nswana 2-youth SA2-TNS-think-RP COMP2 Nswana

$\varnothing \quad$-na -inzh-i na $-\mathrm{ku}-\mathrm{mu}-$ ot $\quad$-a

SAl-TAM-come-fv TAM-INF-OMl-ask for marriage-fv

'The youth thought that Nswana had come to ask her for marriage.' (Lit: 'The youth thought that Nswana has come to ask her for marriage.'

The complementizers námi in (18a), néyi in (18b), níndi in (18c), nétu in (18d), nénu in (18c) and náwu in (18f) introduce complement clauses and are in agreement with the subject of the main clause ami, eyi, mukwénzi 'youth,' the first person plural subject, the second person plural subject, and akwénzi 'youths' respectively of the main clause. Note that the forms of the complementizers are different in each one of the examples $(18 \mathrm{a}-\mathrm{c})$ as they depend on the referent noun or pronoun in the main clause.

Even when the verb of the main clause is imperative, the complementizer agrees with the addressee, as exemplified by the following sentences in (19).

(19) a. Itezháku néyi wáluwañesha yúma.9

$\begin{array}{llll}\text { itezh -a -ku néyi } \quad \text { wu-a -luwañesha } & \text { yi-úma } \\ \text { accept-fv-IMP2sg COMP2sg 2sg-TNS-disturb } & 8 \text {-thing } \\ \text { 'Accept that you disturbed things.' }\end{array}$

${ }^{9}$ In Lunda, verbs are inflected with the morpheme $-k u$, a combination of the locative suffix $-k u$ and the vowel $-u$, in the second person singular in the imperative. Some monosyllabic verbs such as $y a$ 'go,' nwa 'drink' and dá 'eat' take either the suffix - $k u$ or -aña as in dáña 'eat' and yáña 'go'. The locative is also used in subjunctive constructions as a more polite alternative to the imperative form in the second person singular Wutwanakeniku.

wu-tu -anaken-i $-\mathrm{ku}$

2sg-OMlpl-forgive -SUBJ-LOC

'Forgive us.'

The affix $-k u$ is clearly a locative although it has the same form as the second person singular object prefix. In Chokwe, Luchazi and Luvale, the locative suffix occurs as $-k o$, consisting of the locative suffix $-k u$ and the vowel $-o$, and is attached to only monosyllabic verb roots. Words in Lunda do not end in either of the mid vowels $e$ and $o$. Furthermore, first and second person object pronouns never appear after the verb, though third persons do occur as pronouns suffixed to the verb. 
b. Itezénu nénu atwánsi asenda yúma.

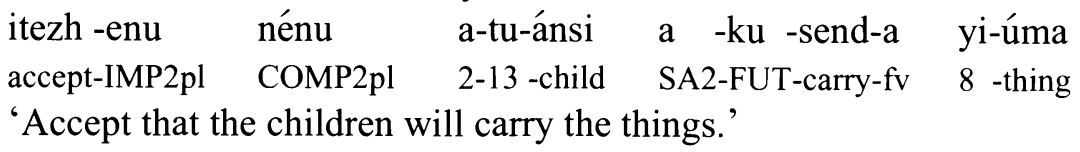

c. Twítezhi nétu twáluwañesha yúma.

\begin{tabular}{|c|c|}
\hline $\begin{array}{l}-\mathrm{i} \\
\mathrm{t}-\mathrm{SUBJ}\end{array}$ & $\begin{array}{l}\text { nétu } \\
\text { COMP1pl }\end{array}$ \\
\hline
\end{tabular}

'Let us accept that we disturbed things.'

The complementizers néyi in (19a), nénu in (19b), and nétu in (19c) are all dependent on the coreferent subjects in the main clauses whose verbs are in the imperative mood.

Lunda differs from most Bantu languages in terms of the features of noun classes; it displays a striking distinction between animate nouns and inanimate nouns. Nouns belonging to classes other than 1 and 2 are subdivided into animates and inanimates. Animate nouns display double prefixes in the plural form, that is, they take both their noun class prefix plus the class 2 noun prefix $a$-. Furthermore, with the exception of possessives, animate nouns trigger class 1 and 2 agreement affixes rather those of the classes to which they belong. This generalization also applies to closely related Bantu languages such as Chokwe, Luchazi, and Luvale (Horton 1949, White 1949, 196?, Doke 1967, and Fleisch 2000). The division of nouns into subcategories may explain why complementizers are restricted to the two classes only. Horton (1949:181) observes that the complementizers for "inanimates are infrequent, but are found in native fables" in Luvale. However, this is very doubtful, as fables use animals which, as already mentioned, employ class 1 and 2 complementizers.

(20) a. Kapela wasulukili muwina.

ka-pela wu -a -suluk-ili mu -wina

12-snake SA1-TNS-slither-RP LOC-hole

'The snake slithered down into the hole.'

b. Atupela asulukili muwina.

a-tu-pela a $\quad$-a -suluk-ili mu -wina

2-13-snake SA1-TNS-slither-RP LOC-hole

'The snakes slithered down into the hole.' 
c. Kapela wámuzhaha, wúchini malóka?

$\begin{array}{lllll}\text { ka-pela wú -a } & \text {-mu-zhah-a } & \text { wú -chin } & \text {-i } & \text { ma-lóka } \\ \text { 12-snake } & \text { 2sg.-TNS-OM-kill -fv } & \text { 2sg.-run away-SUBJ } 6 & \text {-wriggle } \\ \text { 'You killed the snake, why should you run away from the wriggles?" }\end{array}$

d. Kapela wamona nindi chisakala analuwañeshi.

ka-pela wu -a -món-a $\begin{array}{lll}\text { níndi } & \text { chi-sakala } \\ \text { 12-snake SA1-TNS-find -fv COMP1 } & 7 & \text {-nest } \\ \text { a -na -luwañesh-i } & & \\ \text { SA2-TAM-disturb -fv } & \end{array}$
'The snake found that the nest had been disturbed.'

The above examples contain a class 12 noun kapela 'snake' in (20a) and a class 13 atupela 'snakes' (20b) which trigger class 1 and 2 subject agreement markers $w u$ - and $a$-instead of $k a$ - and $t u$-. Note that the nominal subject in (20b) has two noun prefixes, a class 2 noun prefix $a$ - and a class 13 noun prefix $t u$-. Further, in (20c) the left-dislocated nominal object kapela 'snake' triggers the appearance of a class 1 object marker $m u$ - on the verb instead of the class 12 object agreement $k i$ - Even the complementizer níndi in (20d) is triggered by semantic animacy rather than grammatical class 12 to which the subject of the main clause belongs.

Unlike some Bantu languages such as Bemba (Givón 1972a), Kiswahili (Ngonyani 1999), KiKaonde ${ }^{10}$ and other African languages which make use of the complementizer derived from a verb of saying, the morphology of the Lunda subject-agreeing complementizers clearly indicates that they can be traced to the possessive personal pronouns. This distinct feature of complementizers has also been observed in other genetically related Bantu languages such as Luvale (Horton 1949:181), (White 1959), Chokwe (White 196?), and Luchazi (Fleisch 2000:101).

The complementizer prefix $n \iota^{-11}$ might have originated from the first person singular subject prefix. Evidence for this comes from Chokwe, Luchazi, and Luvale, where the first person subject singular prefix $n g u$ - appears to be the

\footnotetext{
${ }^{10}$ KiKaonde (L. 41), a Bantu language spoken in Zambia, uses the complementizer $m b a$ that derives from the verb kwamba 'to say'. As for Bemba (M. 42), the complementizer is $t i$ from the verb ukutila 'to say'.

${ }^{11}$ It must be noted that the prefix $n i$ - is not a copula in Lunda, though it has the shape of the simple copula found in some Bantu languages such as Bemba. Instead the copula is hi- for third persons and $y i$ - for first and second persons in Chokwe, Luchazi, Lunda and Luvale.
} 
source of the complementizer prefix. This is contrary to the claim by Horton (1949:181) and (Fleisch 2000:101) that the complementizer prefix in Luvale and Luchazi derives from the Luvale ideophone gwa which denotes a clacking sound. Had the complemetizer derived from this ideophone, the complementizer prefix in Lunda would have been $n g u$ - like the other three languages, since the high vowel / $\mathrm{u} /$ undergoes the process of glide formation before another vowel. However, Lunda has the same ideophone ngwa which means 'cutting, breaking across'. The ideophone $n g u$ also exists in Lunda, while it is reduplicated ngungungu in Chokwe with the same meaning 'to be in good health'. Thus, Fleisch's observation that the ideophones in Luchazi differ very much from the Luvale ones contradicts his agreement with Horton about the origin of the complementizer prefix found in Chokwe, Luchazi, and Luvale.

\section{Table 3: Subject-Agreeing Complementizers}

$\begin{array}{ll}1 \mathrm{sg} & \text { námi } \\ 1 \mathrm{pl} & \text { nétu } \\ 2 \mathrm{sg} & \text { néyi } \\ 2 \mathrm{pl} & \text { nénu } \\ \text { class 1 } & \text { níndi } \\ \text { class 2 } & \text { náwu }\end{array}$

The selection of the tense in the complement clause does not depend on the tense of the main clause, as the verb of the subject-agreeing complement clauses can be in any tense; it can be in the past, the present or the future.

(21) a. Ashimuna náwu akwinza namelela.
a -a -shimun-a náwu a -ku -inza na-melela SA2-TNS-say -fv COMP2 SA2-FUT-come in -evening
'They said that they would come in the evening.'
(Lit: 'They said that they will come in the evening.')

b. Watóñózhokeli níndi anenzi nakutúña itála.

wu -a -toñozhok-eli níndi a -na -inz -i na -ku -túña itála SA1-TNS-think -RP COMP1 SA2-TAM-come-fv TAM-INF-build house 'He thought that they had come to build a house.' (Lit: 'He thought that they have come to build a house.') 
In (21a), the complement clause is an embedded sentence introduced by a third person plural complementizer náwu, while in (21b) it is introduced by a class 1 complementizer níndi.

In Lunda, verbs of perception, utterance and thought that are used deontically to express 'fear,' 'hope,' 'supposition,' and 'wish' take dependent complement clauses with the verb in indicative future tenses in combination with the sentence adverbs hadaha, hamwaha, hekwawu 'perhaps, may be, possibly', and express irrealis meanings.

(22) Wáfuukula néyi hadaha wukuñanakena.

$\begin{array}{lllll}\text { wu-a } & \text {-fuukul-a } & \text { néyi } & \text { hadaha } & \text { wu -ku - }-\tilde{\text { anaken-a }} \\ \text { 2sg-TNS-suppose-fv } & \text { COMP2sg } & \text { perhaps } & \text { SA1-FUT-OMsg-forgive -fv }\end{array}$

'You supposed that he would forgive me.' (Lit: 'you supposed that he will forgive me')

Wakúhwéleli níndi hamwaha Matewu wámba kamusumbula.

$\begin{array}{llllll}\text { wu -a } & \text {-kuhwelel-el -i } & \text { níndi } & \text { hamwaha } & \text { Matewu } & \text { wu -amba } \\ \text { 1.SA-TNS-hope } & \text {-RP-fv } & \text { COMP1 } & \text { perhaps } & \text { Matewu } & \text { SA1-AUX }\end{array}$

ka -mu -sumbul-a

RFUT-OM1-marry -fv

'She hoped that Matewu would marry her.'

4.4 Direct and indirect quotes. Direct and indirect quotes are structurally indistinguishable as they are both introduced by the same subject-agreeing complementizers. Cross-linguistically, indirect quotes or speeches are characterized by third person pronouns and changes in tense. In other words, the reporting of something said, thought, etc. has deixis adapted to the reporter's speech. However, this is not the case with Lunda. The actual words of the speaker are captured as they are uttered and the deixis is appropriate to the moment when it was made. Changes rarely occur with regard to person and tense, and the deixis is not adapted to the viewpoint of the reporter when quoting someone indirectly. In some cases, though rare, pronoun shifts in the third person pronouns do occur in reported speeches. This phenomenon has also been observed in Luvale (White 1949:72). 
(23) Direct Quote:

a. Womba walezha ñodíndi níndi, "Kumadiki nakuya mwisaña."

Womba wu -a -lezh-a ño -dindi níndi kumadiki

Womba SA1-TNS-tell - $\mathrm{fv}$ wife-POSS1 COMP1 tomorrow

$$
\begin{array}{lll}
\text { ní } \quad \text {-aku-y -a } & \text { mu -i-saña } \\
\text { SA1sg-FUT-go-fv } & \text { LOC-5-bush }
\end{array}
$$

'Womba told his wife (that), "Tomorrow I will go in the bush.",

Indirect Quote:

b. Óna muntu wahósha níndi wakaminzhila.

óna mu-ntu wu -a -hósh-a níndi wu -aka-mu -inzh -ila

IDEM 1 -person SA1-TNS-say -fv COMP1 SA1-FUT-OM1-come-APPL

'That person said that s/he would come for him/her.' ('Lit: That person said that s/he will come for him/her.')

Both the direct quotation in (23a) and the reported discourse in (23b) are introduced by the class 1 complementizer níndi.

The use of direct quotes is more frequent than that of indirect quotes in Lunda. The speaker's actual words are reported exactly as they were uttered. This suggests that indirect discourse might have developed from direct quotations. Consider the following example in which the words of the first person speaking are recorded.

(24) Wela níndi nákenza kumadiki.

wu-a -il -i níndi ní -aka -inz -a kumadiki

1 -TNS-say-fv COMP1sg 1sg-RFUT-come-fv tomorrow

'He said that he would come tomorrow.' (Lit: 'He said that I will come tomorrow.')

When the content of the embedded complement clause is not asserted by the subject of the main clause, that is, when a person reports the words as hearsay or not the actual words of an actual speaker, the class 2 complementizer náwu is used instead of the one agreeing with the subject of the main clause.

(25) Hátiyayi náwu kudi ñoma

hi -a -tiy -a -yi náwu ku -di ñoma

when-SA1-hear-fv-REL1 COMP2 INF-be feast

'when he hears that there is a feast' 
Nátiya nawu azhaha nzovu.

ní -a -tiy -a náwu a

SA1sg-TNS-hear-fv COMP2 SA1-TNS-kill -fv elephant

'I heard that they killed an elephant.'

In the examples in (25), the complementizer náwu does not agree with either the class 1 subject $a$ - or the first person singular $n \iota$-.

The same complementizers also function as question morphemes and are affixed to the question marker $-d i^{12}$ with speech verbs in the position where a complement clause would normally occur.

(26) Andimi anahóshi náwudi?

a-ndimi a -na -hósh-i náwu -di

2-farmer SA2-TAM-say -fv COMP2-Q

'What have the farmers said?'

Namulézheli mwana námidi?

ní -a -mu -lezh-eli mu-ána námi -di

SA1sg-TNS-OM1-tell -RP 1 -child COMP1sg-Q

"What did I tell the child?"

4.5 Verb ellipsis. It is interesting to note that the language allows the verb of the main clause to be deleted leaving only the subject intact in its position, followed immediately by the complementizer that functions as a non-verbal predicate with the understood interpretation and meaning of the verbs of 'saying,' 'thinking,' and 'intention,' etc. ${ }^{13}$ In other words, the verb of the main clause may not be overtly expressed and this phenomenon does not affect the semantics of the entire sentence. The context of an utterance enables the listener or reader to figure out

${ }^{12}$ When a nominal object is questioned, the verb suffixes the wh-word, as shown by the example below with a non-speech verb.
Andimi analetidi?
a-ndimi a-na-let-i-di
2-9.farmer SA2-TAM-bring-fv-Q
'What have the farmers brought?'

${ }^{13}$ In his description of Luvale, Horton (1949:182) observes that the complementizer is used in a copular sense without a verbal antecedent. 
the verb that the speaker or writer leaves out. Despite these elliptical features, the main clause cannot be used as a fragment and the complement clause is not an independent clause as is the case in English (Thompson 2002): ${ }^{14}$ it still remains a subordinate clause. Consider the following examples in which complement clauses are either introduced by a complementizer alone or a complementizer preceded by a noun phrase.

(27) Kabuchi níndi: "Énu anvwáli zhámi, bayi mútonozhoka nénu nakuhósha mázu akasawuntu."

Kabuchi níndi énu a-nvwáli zhi-a -ámi bayi mú-toñozhoka Kabuchi COMP3sg 2pl 1-parent 1 -POSS-1sg CONJ 1pl -think

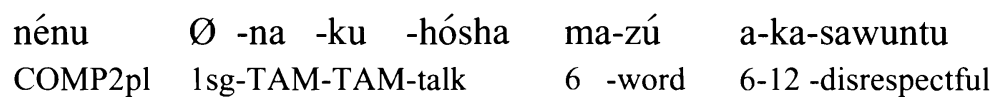

'Kabuchi said: "My parents, do not think that I am saying disrespectful words."

(Chilayi 1989: 25)

(28) Yéna níndi Nswana nénzi nakumwóta.

yéna níndi Nswana $\varnothing$-na - inzh-i na -ku -mu -sumbula

PRON1 COMP1 Nswana SA1-TAM-come-fv with-INF-OM1-marry

'He (thought) that Nswana had come to marry her.'

(29) Étu nétu hímukwinzáku.

étu nétu hi -mú-ku -inz -a-ku

1pl. COMP1pl NEG-2pl -FUT-come-fv-NEG

'We (thought) that you would not come.' (Lit: 'We (thought) that you will not come.')

The main clauses of (27) through (29) consist simply of the noun phrase Kabuchi, the third person singular independent pronoun (class 1) yéna 'him,' and the first person plural independent pronoun etu 'we, us' devoid of the verb followed by the complementizers that introduce dependent complement clauses. The construction in (27) contains a direct quote introduced by the third person singular

${ }^{14}$ According to Thompson (2002: 144-5), complement-taking verbs and that-prefixed clauses can be used by themselves as fragments and in places "where they do not occur in the canonical constructions" in English. That is, some constructions that look like complement clauses are simply independent clauses. In addition, complement-taking verb phrases "occur with no overt associated clauses either in the vicinity or in the previous discourse." 
complementizer níndi agreeing with the subject noun phrase of the main clause Kabuchi, and the direct quote also contains another complement clause introduced by the second person plural complementizer nénu which is in agreement with the first person plural addressee. The main clause in all of the above examples has an implied interpretation of the verb say or think in the main clause followed by either a direct or indirect quote which refers to the words or thought expressed.

The independent subject pronoun, which is frequently used when the subject of the main clause is first or second person, may be left out leaving only the complementizer followed by a complement clause.

(30) Námi twayénu kúnu.

$\begin{array}{lll}\text { námi } & \text { twaya-énu } & \text { ku -nú } \\ \text { COMP1sg } & \text { come -IMP2pl } & \text { LOC-DEM } \\ \text { 'I say, "come here.", } & \end{array}$

Additionally, the subject of the main clause can be introduced by the infinitive kutiya 'to listen, to hear' or kuchinka ${ }^{15}$ which function as discourse markers, that is, the main clause may consist of two elements - an infinitive and the subject plus the complementizer introducing a direct quotative. The verb remains unexpressed and its interpretation depends on the context of the discourse.

(31) Kuchinka Noliya níndi, “Ámi awéni néluki ochu chi nídi nakwila.” kuchinka Noliya níndi ámi awéni Ø -na -iluk-i answering Noliya COMP1 1sg self 1sg-TAM-know-fv

$\begin{array}{llll}\text { ochu } & \text { chi } & \text { ní-di } & \text { na -ku -ila } \\ \text { DEM.7 } & \text { REL7 } & \text { 1sg-COP } & \text { TAM-INF-do }\end{array}$

'Noliya answered, "I, myself, know what I am doing.",

(32) Kutiya wéna náwu: "Túyiđı́mbi."
$\mathrm{ku}$-tíya
wéna
náwu
tú -yi -dimb -i
INF-hear PRON2
COMP2
1pl-OM2-deceive-SUBJ

"And they said: "Let us deceive them.",

\footnotetext{
${ }^{15}$ While the origin of the infinitive kutiya is clear, the meaning of the infinitive kuchinka is not known as it only occurs as a discourse marker in indirect discourses. Its origin cannot be traced.
} 
The infinitive verbs kuchinka and kutiya 'to hear' are used as discourse markers to introduce the subject Noliya and wéna 'they/them' of the main clause in (31) and (32) respectively.

The complementizer following a verbal expression can have an implicit meaning which is different from that expressed by the verb of the main clause. The meaning may refer to an utterance or thought, as illustrated in (33):

(33) Amandumi zhíndi chiyamumwéníwu atiyili kuwáha náwu nayilételi yakuvwála.

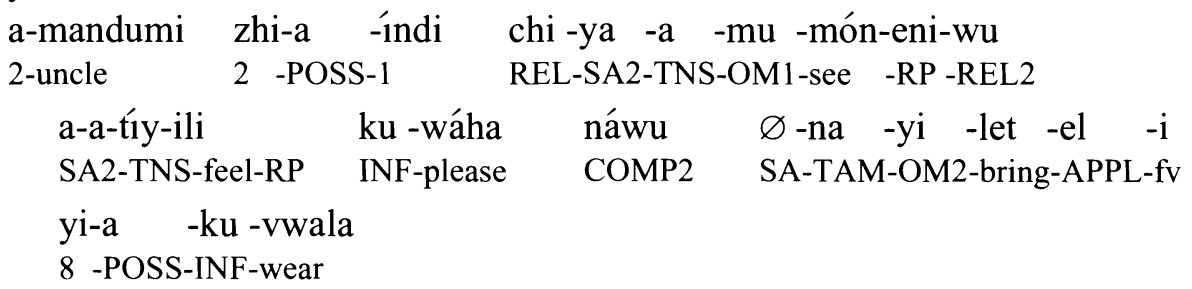

'His uncles felt pleased when they saw him (thinking) that he had brought them clothes.'

(Chilayi 1989:22)

4.5 Object complements. In addition to introducing dependent clauses that function as arguments of other clauses, the same subject-agreeing complementizers occur after certain transitive verbs such as 'name', 'call', 'term', 'mention', and 'write' to introduce a complement that modifies or refers to the direct object or a locative noun. The object complement is comparable to what is referred to as a small clause (Haegeman 2001: 58; Wardhaugh 2003: 85) in the theory of Government and Binding, since the clause is smaller than an ordinary clause and only appears as an embedded clause without an overt verb. The following examples illustrate the use of complementizers introducing clauses that name, describe, or modify the object and the locative noun phrase of the main clause.

(34) a. Antu amutúmbili izhína náwu Chidumbu.

a-ntu a -a -mu -tumb-ili izhína náwu Chidumbu

2-people SA2-TNS-OM1-name-RP name COMP2 Chidumbu

'People named him Chidumbu.'

b. Mwána wamutambikáña níndi yáya.

mu-ána wu -a -mu -tambik-aña níndi yáya

child SA1-TNS-OM1-call -HAB COMP1 1.elder brother/sister

'The child calls him elder brother/sister.' 
c. Anvwáli zháwu ayiténéneña náwu antu abúla nyévulu.

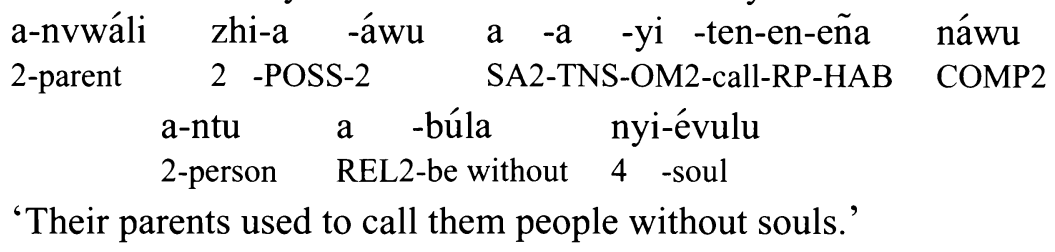

Note that Chidumbu in (34a), yáya 'elder brother/sister' in (34b), and the relativized noun phrase antu abúla nyevulu 'the people without souls' in (34c) are object complements that modify the class 1 and 2 object prefixes $m u$ - and $y i$-. They are introduced by the complementizers náwu in (34a) and (34c), and níndi in (34b), which agree in person and number with the nominal subjects, class 2 antu, class 1 mwána, and the class 2 subject prefix $a$ - 'they' of the main clause.

(35) Wúkuwana hanasónekúwu náwu mukulúmpi washikola. ${ }^{16}$
wú -ku -wan-a
2sg.-FUT-find -fv
ha -a -na -sónek-i -wu
náwu
mu-kulúmpi
REL16-SA2-TAM-write -fv-REL2
COMP2
1 -head
wu -a-shikola
POSS-1 -school
'You will find (the door) where it is written principal.' (Chipoya et al 1995:2)

In example (35), the noun phrase mukulúmpi washikola 'school head/principal,' which is introduced by the class 2 complementizer náwu, is the complement of the omitted locative head noun hachisu 'on the door'. In addition, the form of both the postverbal relativizer $-w u$ and the complementizer indicates that the relative clause has a class 2 subject.

4.6 Subjunctive complement clauses. Some of the evaluative verbal expressions that occur with expletive subjects and take infinitival complement clauses can also take subjunctive complement clauses if a specific person is mentioned, that is, an obligation or necessity is stated as applicable to a specific person. The subject of the subjunctive clause comes directly after the verb of the main clause. The subjunctive mood is characterized by the prefixation of the subject prefix directly

\footnotetext{
${ }^{16}$ The class 2 verbal suffix $-w u$ is used as a class 2 subject marker coreferential with the subject agreement prefix $a$ - when the relativized head noun is either a direct object or a locative noun phrase. This is also found in adverbial constructions.
} 
onto the verb without any tense marker, and the verb stem is coded with the suffix $-i{ }^{17}$ For illustration, consider the following examples:

(36) Chachiwáhi antu anyamuki lélu

\begin{tabular}{|c|c|c|}
\hline chi- & a-ntu & a -nyamuk-i \\
\hline- good & 2-person & SA2-leave \\
\hline
\end{tabular}

'It is better for the people to leave today.' ('Lit: It is better that the people leave today.')

(37) Chatela Matewu aý́. ${ }^{18}$

$\begin{array}{lll}\text { chi-a -telel } \quad-a & \text { Matewu } & \text { a }-y-i \\ 7 \text {-TNS-be necessary-fv } & \text { Matewu } & \text { SAl-go-SUBJ } \\ \text { 'It is necessary that Matewu go.' } & \end{array}$

Subjunctive dependent complement clauses that express purpose, intention, and desire also occur subject-agreeing complementizers. These embedded clauses have irrealis meanings. The absence of the tense marker indicates that the subjunctive lacks an intrinsic temporal reference, as seen in the examples below.

a. Nákéñi námi níkali nkóñi yénu.
$\varnothing$-na -kéñ -i námi
ni -ikal-i
nkóñi
yi-énu
1sg-TAM-want-fv COMP1sg 1sg-be -SUBJ 9.worker
9 -POSS2pl
'I want to be your worker.' (Lit. 'I want that I be your worker.')

b. Túnakéñi nétu kánsi enzi kúnu.
tu -na -kéñ -i nétu
ka-ánsi
a - inz $-\mathrm{i}$
ku -nú
1pl-TAM-want-fv COMP.1pl 1 -child
SAl-come-SUBJ
LOC-DEM
'We want the child to come here.' (Lit. We want that the child come here.')

The subjunctive complement clauses in (38a) and (38b) come immediately after the first person singular and plural complementizers námi and nétu and their verbs ikala 'be, become' and inza 'come' are inflected with the subjunctive morpheme $-i$.

\footnotetext{
${ }^{17}$ The final vowel $-i$ is also found with the present perfect in addition to the tense marker-aspect $n a-$.

${ }^{18}$ The subject prefix $a$ - is used for both classes 1 and 2 in the subjunctive form.
} 
The subjunctive mood in the dependent complement clause is determined by the intrinsic semantic properties of the verb in the main clause, in conjunction with the prototypical inherent meaning of necessity, obligation, desire and wish associated with the subjunctive.

(39) a. Twáyilezha nétu aý1.

tú -a -yi -lezh-a nétu $\quad$ china
lpl-TNS-OM2-tell -fv $\quad$ a $-y-i$
'We told them that they should come.'

b. Amwílili náwu witézhi. ${ }^{19}$
a -a -mu -il -ili náwu wu-itezh-i
SA2-TNS-OM1-tell-RP COMP2 2sg-agree-SUBJ
'They told him that s/he should agree.' (Lit. 'They told him that you should accept.')

The use of the subjunctive embedded clause in (39) can be attributed to the inherent lexically specified semantic properties of the verbs keña 'want, wish' and lezha 'tell' in the main clause, in combination with the inherent meaning of desire and obligation that characterize the subjunctive mood.

It should be noted that complementizers are optional in subjunctive dependent clauses; they can be deleted without a change in their propositional meanings. Examples of a dependent subjunctive clause introduced by a complementizer and one without a complementizer are given in (40a) and (40b).

(40) a. Nákéñi námi kánsi afuntishi nkínga.
$\varnothing$-na -kéñ -i
námi
ka-ánsi
a -funt - sh $-i$
nkínga
1sg-TAM-want-fv COMP1sg 1 -child SA1-return-CAUS-SUBJ 9.bicycle
'I want the child to return the bicycle.' (Lit. 'I want that the child return the bicycle')

\footnotetext{
${ }^{19}$ Generally, the verb ila 'do, make' is used with the meaning of 'tell, order' instead of lezha 'tell, show, explain'.
} 
b. Nákéñi kánsi afuntishi nkínga.
$\varnothing$-na -kén -i ka-ánsi
a -funt -sh -i
nkínga
1sg-TAM-want-fv 12 -child
SA1-return-CAUS-SUBJ
9.bicycle
'I want the child to return the bicycle.' (Lit. 'I want (that) the child return the bicycle')

There is no difference in meaning between infinitival complement clauses and subjunctive complement with types of verbs if the subject of the dependent clause is the same as that of the main clause. Consider the construction in (41a) and its alternative in (41b).

(41) a. Nákéñi níkali nkoñi yénu.
$\varnothing$-na -kéñ -i ń -ikal-i
nkóñi yi-a -énu
1sg-TAM-want-fv 1sg-be -SUBJ 9.worker 9 -POSS-2pl
'I want to be your worker.' (Lit. 'I want that I be your worker.')

b. Nákéñi kwikala nkóñi yénu.
$\varnothing$-na -kéñ -i ku -ikala
nkoñi
yi-a -énu
1sg-TAM-want-fv INF-be
worker
9 -POSS-2pl
'I want to be your worker.'

Subjunctive complement clauses are also employed in discourse for an intended and unfulfilled event or action. In that case, the verb ila 'do' is used in the matrix clause.

(42) Chélili níndi atáli hanýima wamwéni mutúpa.

$$
\begin{aligned}
& \text { chi -a -a -il -ili níndi a -tál -i ha -ný́ma } \\
& \text { when-SA1-TAM-do-RP COMP1 SA1-look-fv LOC-back } \\
& \text { wu -a -món-eni mu-túpa } \\
& \text { SA1-TNS-see-RP } 1 \text {-lion }
\end{aligned}
$$

\section{Conclusion.}

This study has explored the structures of the various types of complement clauses which Lunda has at its disposal. These are infinitive complement clauses, complement clauses without complementizer and those that require the obligatory 
use of complementizers as well as non-finite embedded complements that require complementizers.

Tensed complement clauses that cannot take complementizers occur immediately after the direct object of the main clause. The object follows a limited set of perceptual and evidential complement-talking verbs to code situations and events that are either simultaneous with the main clause or completed prior to those encoded by the verb of the main clause. Embedded interrogative complement clauses are introduced by an invariable complementizer.

The prefix chi-also functions as a complementizer with emotive and evaluative verbs. Declarative complement clauses are introduced by complementizers which obligatorily agree in person and number with the subject of the verb of the main clause. Besides introducing complement clause, the same complementizers are also used to head the complement of the direct object or a locative noun phrase. They equally function as question morphemes affixing the question marker - $d i$ with verbs of utterance. These complementizers derive from personal possessive pronouns, and not from the verb 'say' as is the case in some Bantu languages. Depending on the properties of certain verbs, complementizers can be optional in subjunctive complement clauses.

It has been noted that some of the evaluative verbal expressions with expletive subjects that take infinitival complement clauses can also take subjunctive complement clauses if a specific person is mentioned.

\section{REFERENCES}

Chilayi, M.S. 1989. Chihandilu cha Kabuchi. Lusaka: Kenneth Kaunda Foundation.

Chipoya, Albert, et al. 1995. Lunda Mañu: Mukanda Wakadizi. Lusaka: ZEPH.

Doke, Clement M. 1967. Bantu: Modern Grammatical, Phonological and Lexicological Studies Since 1860. London: International African Institute.

Du Plessis, Jacobus A. 1982. "The analysis of the infinitive". Journal of the African Language Association of Southern Africa. 2.2: 18-48. 
Fisher, M. K. 1984. Lunda-Ndembu Handbook. Lusaka: Neczam.

Fleisch, Axel. 2000. Lucazi Grammar: A Morphosemantic Analysis. Köln: Rüdiger Köppe Verlag.

Givón, Talmy. 1972a. Studies in ChiBemba and Bantu Grammar. Studies in African Linguistics, Supplement 3. Los Angeles: UCLA.

Givón, Talmy. 1990. Syntax: A Functional-Typological Introduction, Vol II. Amsterdam: John Benjamins.

Givón, Talmy. 2001. Syntax: An Introduction, Vol II. Amsterdam: John Benjamins.

Haegeman, Liliane. 2001. Introduction to Government and Binding Theory. Second Edition. Oxford and Cambridge: Blackwell.

Horton, Alonzo E. 1949. A Grammar of Luvale. Johannesburg: Witwatersrand University Press.

Kakoma, Ben C. 1988. Noliya. Lusaka: Kenneth Kaunda Foundation.

Kawasha, Boniface. 2003. Lunda Grammar: A Morphosyntactic and Semantic Analysis. Eugene: University of Oregon, Doctoral dissertation.

Keenan, Edward L. 1976a. "'Some universals definition of subjects"'. Subject and Topic, ed. by C. Li. New York: Academic Press. Pp 303-333.

Matoka, Brighton K. 1995. Sayitamba. Lusaka: Neczam.

Ngonyani, Deo. 1999. "X-movement in Kiswahili relative verbs". Linguistic Analysis 29: 137-159.

Thompson, Sandra A. 2002. “'Object complements' and conversation: towards a realistic account." Studies in Language 26: 125-164. 
Wardhaugh, Ronald. 2003. Understanding English Grammar: A Linguistic Approach. Second Edition. Oxford: Blackwell.

White, Charles M.N. 196? A Chokwe Grammar. White Fathers and Northern Rhodesia and Nyasaland Publications Bureau.

White, Charles M.N. 1949. A Short Lwena Grammar. London: Longmans.

White, Charles M.N. 1944. "The noun prefixes of the West-Central zone of Bantu languages". African Studies 3: 153-160.

Department of Liberal Arts

[received July 13, 2005

Savannah State University accepted July 3, 2006]

128 Payne Hall

Savannah, GA 31404

bkawasha@yahoo.com 